\title{
A BIZTONSÁGI RENDSZEREK FELHASZNÁLÓI ATTITŰDJE, ÉRTÉKELÉSE ÉS BEFOLYÁSOLÁSÁNAK LEHETŐSÉGEI
}

\author{
THE ATTITUDES, ASSESSMENT AND INFLUENCE OF \\ SECURITY SYSTEMS USERS
}

\author{
OTTI Csaba; VALOCIKOVÁ Cyntia \\ (ORCID ID: 0000-0002-9266-639X); (ORCID ID: 0000-0003-3541-4222) \\ otti.csaba@bgk.uni-obuda.hu; valocikova.cyntia@phd.uni-obuda.hu
}

\begin{abstract}
Absztrakt
A biztonsági vezetők nap mint nap szembesülnek a biztonsági rendszerek bevezetésének kihívásaival. Minden biztonsági fejlesztés kulcspontja, hogy a felhasználók képesek és hajlandók-e megfelelően használni a rendszert. Biometrikus rendszer bevezetésénél további problémát jelent, hogy az algoritmusok valószínűségi változókkal dolgoznak, így a felhasználók sosem lehetnek biztosak abban, hogy 100\% pontossággal azonositja öket az eszköz, így téves elutasítások keletkeznek. A felhasználói elfogadottságot jelentősen befolyásolja a felhasználók attitüdje, ezen belül az elöítéletek és a tévhitek is. A felhasználói attitüd és viselkedés komolyan befolyásolható megfelelö tréninggel, illetve az elköteleződés javításával. Ezek a tényezők hatékonyan javithatók a véleményvezérek azonosításával és a projektbe történő bevonásával. Az azonosítás történhet szociometriai felméréssel. Jelen tanulmányban megismertetem a biztonsági vezetőkkel ezeket a módszereket annak érdekében, hogy képesek legyenek a bevezetendő biztonsági rendszer elfogadottságát növelni és biztosítani a projekt sikerét.
\end{abstract}

\section{害}

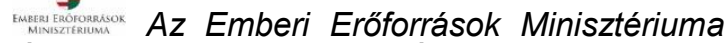
ÚNKP-18-3-III. kódszámú Új Nemzeti Kiválóság Programjának támogatásával készült.

Kulcsszavak: biometrikus rendszer, felhasználói attitüd, elfogadottság

\begin{abstract}
The security managers have to face security management system's implement problems on a daily basis. The key point is in all security improvements whether the users are able and willing to use the system properly. It is even more difficult when biometric systems should be implemented because the algorithms operate with probabilities and the users can never be sure that they are recognized with $100 \%$ accuracy. The user acceptance is strongly affected by user attitude which contains preconceptions and misconceptions. User attitude and behavior can influence by appropriate trainings and user engagement. To improve the efficiency of dissemination of knowledge concerning these attitudes it is thus also important to be able to identify opinion leaders in an organization in an efficient and reliable way. In this paper several typical questions are discussed and associated with the measurement of user experience. I show how the answers can be acquired even if the users don't have access to computers in an organization.
\end{abstract}

Keywords: biometric system, user attitude, acceptance 


\section{BEVEZETÉS}

A biometrikus rendszerek használatának gyakorisága évről évre nő, melyet elsősorban a technológia fejlődése és az innováció tesz lehetővé. A Tractica piackutató cég előrejelzése (2017) szerint a biometrikus rendszerek eladásából származó bevétel 2025-ig évi átlagos 22,9\%-kal fog nőni, a legnagyobb piacát pedig az ázsiai és csendes-óceáni térség jelenti. Ennek oka a növekvő népesség, erősödő gazdaság és a fokozódó igény a biometrikus megoldásokra. A jelentés a biometrikus rendszerekből származó globális bevételt 2025-re közel 15,1 milliárd dollárra becsüli [1]. Érdemesnek tartjuk pontosítani, mit is értünk a biometria és a biometrikus rendszerek kifejezései alatt. Varga Domonkos és Oláh András (2004) akadémikusok megfogalmazásában: „A biometria az emberek egyedi, változtathatatlan jellemzöinek számszerü leírásának tudománya. Jelen esetben a biometriát úgy lehet meghatározni, mint olyan mérhetö testi, vagy viselkedésbeli jellemvonások összességét, amelyek mérése alkalmas arra, hogy egy adott személy azonosságát ellenörizni lehessen (biometriák: ujjlenyomat, arc, kézgeometria, hang, aláirás, gépelési dinamika, DNS, írisz és retina). A biometriai azonositás célja olyan biztonsági rendszerek kialakitása, melyek az egyént nem egy kód és egy kártya segitségével azonositja (ami bárkinek birtokába kerülhet), hanem saját személyi tulajdonságai alapján ismeri fel [2, p. 40]." A biometrikus rendszerek elterjedését több tényező is elösegítette, mint a jelszavak számának folyamatos növekedése, ezek menedzselésével járó költségek gyarapodása, az innováció vagy a kényes adatokhoz való hozzájutás biztonságosabbá tétele. A rendszer tervezésénél nem csupán technikai, de nem technikai szempontokat is figyelembe kell venni, mint a megbízhatóság vagy a kényelem melyek a berendezés hosszú távú, sikeres üzemeltetéséhez elengedhetetlenek. Ezekben a tényezőkben rejlő kockázatok azonban nem elsősorban technológiai, mint inkább felhasználói eredetüek [2]. A rendszer felhasználói számára fontos, hogy a rendszer müködéséhez szükséges mintavétel során szolgáltatott adatok biztonságban legyenek, és a rendszer használata hosszú távon ne járjon kényelmetlenséggel. Ezek a szempontok jelentik a felhasználói elfogadottság alapját is, azonban a biometrikus rendszerek elfogadottságára számos további tényező gyakorol hatást, mint a felhasználók attitűdje, vagy a csoporthatás, amikor nagyobb létszámú munkavállalói csoportok vagy tömegtartózkodású objektumok felhasználói egymást befolyásolják az attitüd kialakításában [3].

A tanulmányban bemutatjuk az attitüd vizsgálat tárgyalt területre vonatkozó főbb módszereit és azzal kapcsolatos szociometriai méréseket. Segítségükkel közelebb hozható a szakemberek számára is jól érthető és felhasználható eszközök, amelyek segítséget nyújtanak a felhasználók viselkedésének megértésében és a biometrikus rendszerek elfogadottságának fokozásában. Szakirodalmi áttekintéssel feltérképezzük azokat az eljárásokat, melyek használatával befolyásolható a rendszer felhasználóinak attitűdje, illetve elemezhető és azonosítható annak jelentős pontjai. Elsősorban a rendszer felhasználásának előnyeit és hátrányait, majd az attitüd mérésére vonatkozó lehetőségeket mutatjuk be, ezt követően pedig a szociometria eszköztárát vetítjük ki a vizsgált területre. Az eszközök megismerésével lehetőséget biztosítunk a szakemberek számára a biometrikus rendszerek elfogadottságának növelésére és kínálatának egy hatékonyabb módjára.

Kutatásainkat az MTA TK „Lendület” RECENS kutatómühely keretein belül folytattuk Dr. Bodor-Eranus Eliza Hajnalka témavezető támogatásával, mely lehetőségért ezúton is köszönetet mondunk.

\section{A BIOMETRIKUS RENDSZEREK JELLEGZETESSÉGEI, FÓKUSZÁLVA A FELHASZNÁLÓRA}

A biometrikus azonosításra a felhasználók egyedi, permanens és mérhető jellemzői alkalmasak. Fontos továbbá, hogy ezek a jellemzők elfogadhatóak és megbízhatóak legyenek, tehát ne 
akadályozzák higiéniai vagy hamisítható tényezők. Ennek ellenére gyakori eset, hogy egyes biometrikus rendszereket megtévesztenek a felhasználók. Tipikus példája, amikor a 2000-es évek elején egy biometrikus rendszereket gyártó cég piacra dobott egy olyan ujjlenyomat azonosító rendszert, mely élö ujjat fogadott el. Később azonban rájöttek, hogy a beolvasó szenzorra vitt leheletet a rendszer élő ujjnyomatként azonosít, hiszen a szenzoron rajta maradt az előző belépő ujjnyomata, amelyet a lehelést követően újra aktivált a rendszer. A hiba jelentősen csökkentette a rendszer megbízhatóságát. Ez csak egy eset a számos lehetséges hiba közül, így a biometrikus rendszerek megbízhatósága nem minden esetben kétségbevonhatatlan [4]. A biometrikus rendszerek általános teljesítőképességének elemzésére alkalmas a Zephyr analízis (lásd 1. ábra), mely eredetileg a pilóták navigációs segédeszköze volt a repülési térképek könnyebb megjelenítésére a pilótafülkékben.

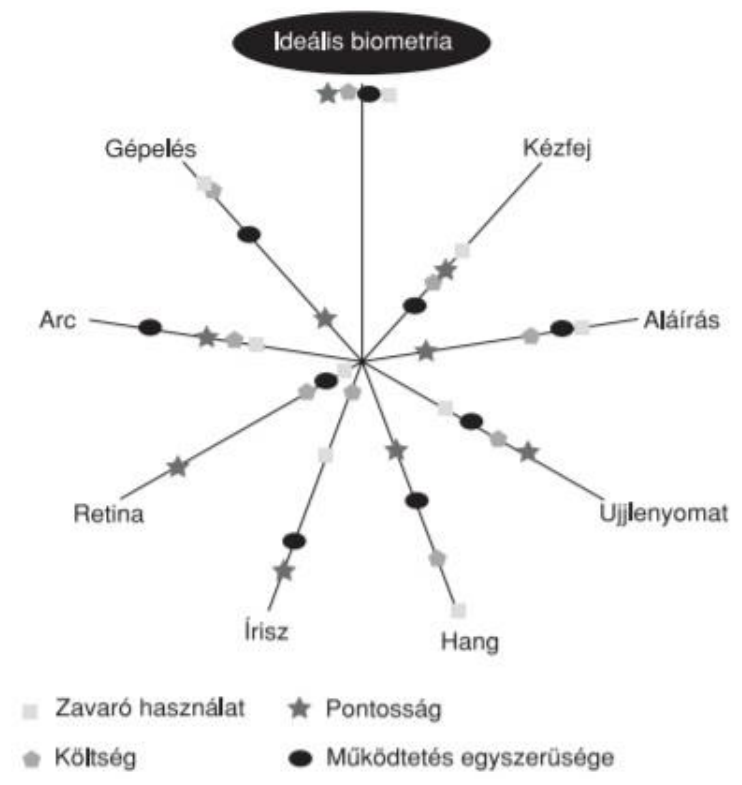

1. ábra Zephyr-analízis felosztása

Ezt az eljárást ültették át (Nemzetközi Biometrikus Társaság) a biometriába. Az analízis az azonosítót négy szempont alapján elemzi: zavaró használat, pontosság, költség és müködtetés egyszerüsége. Az origóhoz közeli értékek a kedvezőtlen a távoli a kedvező minősítést jelentik [2] [5]. Habár az analízist 2002-ben végezték el, és az egyes értékek ez idő alatt megváltozhattak, az analízis alapját képező szempontok kiindulópontot jelentenek a biometrikus rendszerek elfogadottságának mérésében. Az egyik lényegi szempont a pontosság, mely a rendszer megbízhatóságára utal. Ennek elemzésére két fő mérőszám szolgál, a hibás elfogadási arány (FAR) és a hibás visszautasítási arány (FRR). Az elöbbi az illetéktelen behatoló téves elfogadásának a valószínűséget, míg az utóbbi a regisztrált felhasználó téves visszautasításának valószínüségét jelenti. Az illetéktelenek kiszűrése mellett a felhasználó számára fontos a gyors és pontos azonosítás is. Ide kapcsolódik az azonosítók kezelésének egyszerüsége, mely lehetővé teszi a felhasználó nehézségektől mentes tanulását. A felhasználó elfogadásának szempontjából lényeges tényező a zavaró használat, mely a kényelmes és megbízható azonosítás elősegítését foglalja magába [2] [6].

A biometrikus azonosítás további, felhasználói eredetủ nehézségeit jelenthetik a tévhitek, a személyazonosság és adatlopástól való félelem vagy az etika figyelmen kívül hagyása (megkülönböztetés az azonosítás által). Ezeknek a tényezöknek a forrása leggyakrabban az információ és kommunikáció hiányából, vagy éppen a félreinformálásból ered. A felhasználók nem megbízható forrásokból való tájékozódása, a média általi félrevezetés szintén okozhatja a biometrikus azonosítással szembeni elutasítás mértékét. A bizalom kiépítéséhez azonban 
elengedhetetlen a megfelelő információszolgáltatás, a hiteles információbiztonsági menedzsment vagy az ideális jogszabályi háttér kidolgozása. Ezzel párhuzamosan más, a felhasználó attitüdjére és magatartására vonatkozó tényezők is befolyásolhatják a felhasználók biometrikus rendszerekre vonatkozó megítélését. Hatást gyakorolnak rá továbbá a demográfiai jellemzők is, mint az életkor vagy a szociális állapot [7] [8]. A továbbiakban a felhasználó hozzáállását, attitűdjét befolyásoló tényezőket részletezzük, melyek mérésével megvizsgálható a felhasználói célcsoport biometrikus rendszerekre vonatkozó magatartása.

\section{A FELHASZNÁLÓI ATTITŰDÖT BEFOLYÁSOLÓ TÉNYEZÖK BEMUTATÁSA}

A társadalmi viselkedés elemzésére leggyakrabban az attitüd vizsgálatán keresztül vezet az út. Az attitüd fogalmát számos kutató és filozófus - mint Thrustone, Köhler, Banaji vagy Chaiken - definiálta, azonban lényegre törően Allport (1935) fogalmazott, aki szerint az attitűd: ,, [...] olyan mentális és neurális készenléti állapot, amely a tapasztalatokon keresztül szervezödik és irányító vagy dinamikus befolyást gyakorol a személynek minden tárgyra és helyzetre adott válaszában, amely ezzel kapcsolatban áll [9, p. 8].” A legtöbb definíció azonban egyetért abban, hogy az attitüd érzelmi viselkedés. Atkinson et al. (1999) szerint „az attitüdök tanulmányozásának egyik fó oka az az elvárás, hogy lehetövé tegyék a viselkedés bejóslását [10, p. 566]." A viselkedés értelmezésére alkalmas folyamat az attribúció, problémája pedig a viselkedés okára való következtetés. Attól függően, hogy a figyelt viselkedés belső (attitűd, személyiség) vagy külső (szituációs körülmények) eredetü megkülönböztetünk diszpozicionális és szituációs attribúciót. A felhasználó viselkedésének elemzésekor mindkét tényező fontos szerepet játszik. Atkinson és Hilgard közösen írt könyvükben az attitüd komponenseit részletezi, melyek meghatározzák egy személy magatartását. A szerzők az attítüdöt kognitív, affektív és konatív összetevők együtteseként értelmezik. A kognitív tényező az ismeret, nézet, amit vallunk, az affektív az érzelmi változó míg a konatív a viselkedésre vonatkozó komponens. Esetünkben azt érdemes felmérni tehát, a felhasználó mennyire ismeri, mit tud a biometrikus rendszerekről (kognitív), hogyan érez, kedveli-e az ilyen típusú rendszereket (affektív), és milyen gyakran használja a biometrikus azonosítást (konatív). Ezek kvalitatív vagy kvantitatív vizsgálatával meghatározható a felhasználói csoportok általános attitüdje, azonosíthatók a kritikus pontok és a menedzserek beavatkozhatnak az attitüd pozitív irányba terelése érdekében [11]. Az attitüdöt azonban közvetlenül olyan tényezök is befolyásolhatják, mint az egyén személyisége vagy szociodemográfiai jellemzői (nem, kor, képzettség, foglalkozás, jövedelem). Ezen felül az attitüd különböző funkciót láthat el, hiszen eltérő okok eltérő személyiségeknél ugyanazon attitüdöt válhatják ki. A funkciót befolyásolja a megváltoztathatóság és a konzisztencia egyaránt. Ilyen funkció az instrumentális, mely a jutalom megszerzésére és a büntetés elkerülésére irányuló megnyilvánulás. Ebben az esetben az egyént meg kell győzni arról, hogy az egyik alternatíva nagyobb haszonnal jár, mondjuk rábeszéljük a felhasználót, hogy a biometrikus azonosítással rengeteg időt spórolhat. $\mathrm{Az}$ ismereti funkció a birtokunkban lévő információt jelenti. Gyakran azonban az attitüdök leegyszerüsítik a való életet, és torzítják a valóság észlelését. Esetünkben a felhasználó téves forrásokból kiindulva tarthat attól, hogy az azonosítás hosszútávan károsítja az azonosításhoz használt érzékszervét (pl. szem). Az értékkifejezö funkció az egyén értékét tükröző tényezőket jelenti, ha tegyük fel a felhasználó olyan közegben nevelkedik, ahol erős a személyes tér védelme, vagy a zárkózottság, nehezebben kötelezheti el magát a biometrikus azonosítás mellett. Ezek az attitüdök rögződnek az egyénben, nehezen változnak. Az énvédö funkció az egyént fenyegető veszélyektől való oltalmat jelenti, itt jelenik meg az elöítélet és a tévhit. Végül a szociális igazodási funkció, amelyet a társadalmi beilleszkedés, a közösség általi elfogadás 
igénye jelenti. A felhasználói közösség tagjainak hozzáállását tehát nagy mértékben befolyásolja a csoport közösen vallott nézetei, értékei, így még a másképp vélekedő tagok attitüdje is igazodhat a csoportéhoz a csoportnyomás hatására. A csoportnyomás és csoportszellem a kritikus véleménnyel bíró, vagyis véleményvezér csoporttagok előfeltevései által érvényesül leginkább [12] [13].

\section{Véleményvezetők - a kapcsolatháló kulcsszereplői}

A véleményvezetők azonosításával és vizsgálatával számos elmélet foglalkozik. Az egyik Lowery és DeFleur (1920) kutatása, mely szerint a média nagymértékben képes befolyásolni az egyének attitűdjét [14]. Ezzel szemben néhány elmélet - Lazarfeld (1944) vagy Katz (1957) - cáfolja, mely szerint a média uralná a társadalmat. A kutatók a személyes kapcsolatok és a véleményvezetők együttes befolyását tartják a legfontosabbnak. A véleményvezetők befolyása függ a társadalmi ranglétrában elfoglalt helyüktől, a csoporthoz való tartozástól és az életciklusban elfoglalt helyeiktől [15]. Katz későbbi kutatásában (1963) támpontot adott, hogyan azonosíthatók a véleményvezérek. Elsősorban a véleményvezér személye, másodsorban az általa ismert területek/információk, végül a véleményvezér által ismert egyének a lényeges szempontok. Rogers (1962) további módszereket említ a véleményvezérek azonosítására, melyek közül a szociometria módszere meghatározó (ez a tanulmány későbbi fejezetében részletezésre kerül) [16]. További kutatások részletezik - Childers (1986) vagy Cosmas és Sheth (1980) - hogy a véleményvezérek tapasztaltak, kreatívak és széleskörü ismeretekkel rendelkeznek. Weimann (1994) szerint a véleményvezérek, vagy befolyásolók szakértők a saját területükön, azonban nem feltétlenül rendelkeznek magasabb intelligenciával a vezetőkhöz képest. Habár, innovatívabbak és kockázatvállalóbbak társaiknál. A kutató véleménye szerint kötődnek a társadalmi normákhoz, és a társadalmi megbecsültségük is magasabb. Végül a kutatása igazolta, hogy a véleményvezetőkre nagyobb hatást gyakorol a média, mint más vezetőkre [17]. A véleményvezetők ,,[..] azok az egyének, akik befolyásolnak másokat a közvetlen környezetükben [18, p. 31]. " Ezért fontos az azonosításuk, hiszen ők az a húzóerő, amely nagy mértékben befolyásolhatja és formálhatja egy csoport attitüdjét. A szociológiai és társadalmi vizsgálatok nagy hangsúlyt fektetnek a kapcsolathálózat kulcsszereplőinek a vizsgálatára, ilyen szereplő tehát a véleményvezér, akit Mérei (1996) szociometriai sztárnak is nevez. Ahogyan korábban már szó esett, a véleményvezetők azonosítására Rogers (1962) négy módszert ismertetett: a szociometria, az informátorok értékelése, az önértékelés és a részt vevő megfigyelés [18]. Az ilyen típusú személyiségek vizsgálatához a négy módszer közül a szociometriát emeljük ki, hiszen gyakorlatban könnyen alkalmazható, és átfogó képet kínál.

\section{A SZOCIOMETRIA MÓDSZERE - A CSOPORTSZERKEZET FELTÉRKÉPEZÉSE}

A szociometria a szociálpszichológiai elemzések között tekintélyes helyet foglal el. A módszer célja a csoportok személyközi kapcsolatainak feltárása és ez alapján a társas alakzat kidolgozása [19]. A hagyományos szociometria Jacob Lévy Moreno román származású pszichológus nevéhez füződik. Moreno volt az első kutató, aki megvizsgálta az egyén helyét a csoportban. A módszer kiindulópontja a spontán létrejövő társulások hálózata az intézményes rendszerekben. Moreno ezen társulások okait, miértjét vizsgálta, a módszer középpontjában pedig a rokonszenv-ellenszenv kapcsolata áll. A szociometria vizsgálatának egyik feltétele, hogy valós környezeteben, reális közösségben kell elvégezni. A feltételeknek megfelelö valós környezetben a résztvevőknek (közösség tagjai) szubjektív kérdésekre kell felelniük, melyben a spontán kapcsolódások választása vizsgálható. Moreno szerint a társas hálózatok tagjai 
közötti kapcsolat elsősorban érzelmi jellegü, melyet a rokonszenv és ellenszenv érzelmi köteléke ír le, mint a „megvásárolhatatan” emocionális reakció eszköze. A szubjektív kérdések a módszer kritériumai, amelyek az adott csoportra érvényes normát tükrözik. Moreno három kiindulási kritériumot jelölt meg, az együttélést (kivel élne szívesen), együtt dolgozást és együttes társas életet (mint, kiket hívna meg szívesen vendégségbe) [20].

A szociogram megrajzolásával körvonalazódik a társas hálózatban megjelenő kapcsolatok térképe. A grafikus ábrázolás néhány ismérve: az egyéneket bekarikázott szám jelöli, a bekarikázott számok közötti vonal pedig a kölcsönös választást jelenti. Minél több kritérium esetén választották egymást a csoporttagok, a kapcsolat annál erősebb (több párhuzamos vonal jelöli). Az egyoldalú kapcsolatokat nem ábrázolja a szociogram (perem típus, a magány esete), azonban következtetéseket engedhet levonni. A kölcsönös kapcsolat megjelenhet leggyakrabban két, három, illetve négy személy között. Az ábrázolás további esete a csillag (egy személynek több a kölcsönös kapcsolata, de azok között nincs kapcsolat, akik hozzá kötődnek), továbbá a lánc (párok egymáshoz kapcsolódása) [20] [21]. A 2. ábrán látható egy hagyományos, laza társas szerkezetü csoport kölcsönösségi térképe, ahol megfigyelhető a klikkesedés [22].
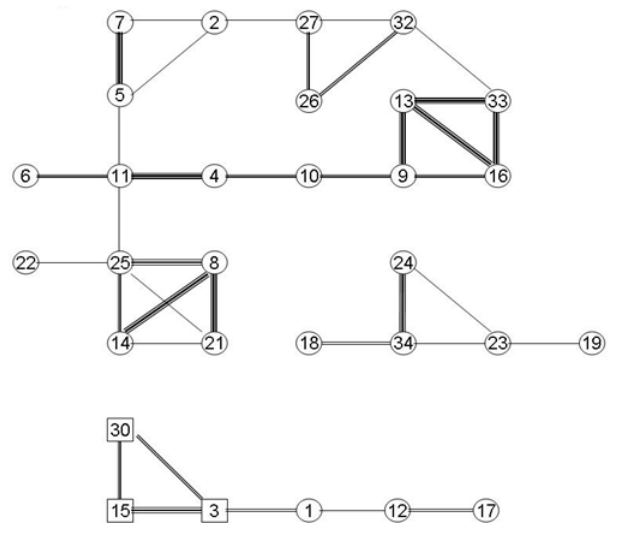

2. ábra Hagyományos csoport szociogramja
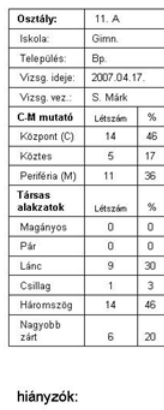

(20) (28)

$29 \quad$ (31)

Habár a szociometriát alapvetően az oktatásban használják leggyakrabban, a módszer kiválóan átültethető bármilyen intézményes csoport vizsgálatára. Moreno szociometria módszerét Mérei Ferenc pszichológus továbbfejlesztette, és kidolgozta a többszempontú szociometriát, amely nem csupán az egyén helyét elemzi a közösségben, hanem magát a közösséget is, továbbá az egyén csoportban betöltött funkcióját. A Moreno féle szociometriában használt választási kritériumok eltérnek a Mérei féle többszempontú szociometriától, hiszen itt már a közösség választásának indítékára, egyéni készségekre vagy tulajdonságokra is fókuszál. Olyan kritériumokat vesz figyelembe, mint a közösségben betöltött funkció (mely lehet bíró, szervező, vezető), egyéni adottságok vagy népszerüség. A többszempontú vizsgálat adatgyüjtésének eszköze a kérdőív, eredményeit pedig kölcsönösségi és gyakorisági táblázatban rögzítik [20] [22]. A kölcsönösségi táblázat olyan mátrix, amelyben a megkérdezettek névsora a mátrix két tengelyén szerepelnek, a mezőkben pedig a rokonszenvi választás kerül feltüntetésre, majd az értékeket soronként és oszloponként összesítik. A gyakorisági táblázat esetében a névsor a mátrix függőleges tengelyére, a választási kritériumok a vízszintes tengelyre kerülnek. A névsor az intézményben betöltött rangsor, vagy munkahelyi beosztás alapján kerül felvázolásra. A vizsgált csoport társas hálózatának ábrázolására alkalmas még a szociomátrix, mely lehetőséget nyújt a szociometriai mutatók kiszámításához, elemzéséhez. Bemutatunk néhány mutatót, mely a társas hálózat jellemzésére ad módot. 
Ezek közül elsősorban a szerkezeti mutatókat ismertetjük, mégpedig a CM (centrálismarginális) mutatót, mely megmutatja a vizsgált csoport központját és a körülötte lévő perem kiterjedését.

A kohéziós mutatók azt fejezik ki, hogy a vizsgált csoportot milyen mértékben írja le az összetartozás tudata. Kohéziós mutató a kölcsönösségi index, mely megmutatja, hogy a társas mezőben szereplő egyének hány százalékának van kölcsönös kapcsolata. Az index képletét az 1. egyenlet szemlélteti, ahol SZQ a kölcsönös kapcsolatokkal rendelkező személyek száma. Az index átlagértéke 85-90\% közé esik. Az érték minél magasabb, annál kevesebb a magányos egyén a csoportban.

$$
K I=100 \frac{S Z Q}{N}
$$

A sürüségi index a csoport létszámának és a kölcsönös kapcsolatok számának aránya. A közösség stabilitását mutatja, mégpedig, hogy egy egyénre hány kapcsolat jut. Átlagértéke 0,91,1 közé esik ( 1 érték felett stabil, 0,8 érték alatt laza társas csoportot jelent, 0,6 alatt viszont már csoportra sem utal), képletét a 2. egyenlet szemlélteti.

$$
S I=\frac{S Q}{2 N}
$$

A kohéziós index az fejezi ki, hogy a vizsgált társas kapcsolatok számának hány százaléka realizálódott. Tehát, hogy milyen a csoport együttes teljesítménye. Képletét a 3. egyenlet mutatja, ahol a számláló a kölcsönös kapcsolatok számát, a nevező az összes lehetséges kölcsönös kapcsolat számát jelenti. Átlagértéke 10-13\% között mozog. A magas érték nagy teljesítményt és sikeres közös munkát jelez, az alacsony viszont gyér teljesítményt.

$$
S K O H=\frac{200 S Q}{N(N-1)}
$$

A viszonzott kapcsolatok mutatója megmutatja, hány százaléka kölcsönös a vizsgált kapcsolatoknak. A képletet a 4. egyenlet mutatja, ahol dn az összes választás száma. Átlagértéke 40-50\%, a magas értéket érdemes a sürüségi indexel együtt elemezni, ahol, ha szintén magas az érték akkor egy jól összeszokott csapatról beszélhetünk. Alacsony érték esetében kevés a viszonzott kapcsolat, ha régóta együtt lévő csoportról beszélünk, akkor az alacsony érték jelezhet klikkesedést is.

$$
\text { SKOHER }=\frac{100 S Q}{d n}
$$

Végül érdemes megemlíteni a csoportlégkör mutatót (lásd 1. táblázat), mely a választások eloszlását vizsgálja.

\begin{tabular}{|c|c|c|c|}
\hline & Rokonszenv & Funkció & Szempont \\
\hline Alacsony érték & $0-1,9$ & $0-2,5$ & Szubjektív választás \\
\hline Közepes érték & $2-2,5$ & $2,6-3,9$ & \\
\hline Magas érték & 2,6 & 4 & $\begin{array}{c}\text { Normához igazodó } \\
\text { választás }\end{array}$ \\
\hline
\end{tabular}

1. táblázat A csoportlégkör mutatója 
A rokonszenv és funkcióra vonatkozó kérdések eloszlásának aránya segít eligazodni abban, hogy milyen szempont határozza meg a csoportban a választást. A rokonszenvi választást szubjektív szempontok befolyásolják, azonban a funkcionális választás esetében a tehetség, készség alapján kell választani. Ha a csoport tagjai a barátjukat választják egy-egy feladatra az érzelem vezérelt müködést jelent, ha viszont a funkciót betöltőkkel szeretnének barátkozni az tekintély vezérelt müködést jelent [20] [23]. A szociometria segítségével a csoport belső értékeire, nézeteire lehet következtetni és megmutatja milyen kiemelkedő tulajdonságok jellemzik a vizsgált társas csoportot. Ezen felül megmutatja a jelentős, fontos személy csoportban betöltött szerepét. A vizsgálat hozzájárul, hogy a csoportról alkotott kérdéseket és problémákat megválaszolja. Megmutatják többek között a nemek közötti különbségeket, feltárják a véleményvezért valamint támpontot nyújtanak a csoport közösen vallott attitüdjének feltárásában. Habár a szociometriát leggyakrabban a pedagógiai gyakorlatban alkalmazzák, a többszempontú szociometria alkalmas az üzleti életben megjelenő dolgozói csoportok elemzésére is, hiszen segítséget nyújt abban, hogy megtaláljuk a közvélemény befolyásolására legalkalmasabb csatornát [20] [24].

\section{KÖVETKEZTETÉSEK}

A biometrikus rendszerek felhasználói elfogadottsága nem minden esetben pozitív, hiszen a kommunikáció hiánya, félreinformálás, tévhitek vagy a negatív attitüd eredményezhetik a biometrikus azonosítás rossz vagy hamis megítélését. A viselkedés alakítását az attitüd megismerésén és formálásán keresztül lehet elérni. Az attitüd vizsgálatánál az affektív, konatív és kognitív összetevőket, valamint az attitüd funkcióját együttesen kell megállapítani. A biometrikus azonosítók elfogadását nem egyénenként, hanem csoporton belül lehet a leghatékonyabban vizsgálni. Mivel a csoport közös magatartását nagyban befolyásolja a véleményvezérek magatartása, ezért elengedhetetlen annak részletes vizsgálata. A tanulmányban bemutatásra került néhány elmélet és módszer, mely kiindulópontot jelent a véleményvezérek azonosítására a csoporton belül. Kiemeltük a szociometria módszerét, mint a társas kapcsolatok vizsgálatának egy fontos eszközét. Bemutattuk a hagyományos és többszempontú szociometria vizsgálatát és jellegzetességeit. Részleteztük a szociomátrix és mutatóinak lényeges pontjait, melyek kiszámításával és a vizsgált csoporttagok kapcsolatának ábrázolásával tisztázódnak az egyének csoportban betöltött szerepei, magatartásai és a véleményvezérek személye. A kutatás betekintést engedett a felhasználói elfogadottság problémáinak megismeréséhez a biometrikus rendszerek iránt, továbbá lehetőséget nyújtott az attitüd és magatartás befolyásolására a különböző vizsgálati módszerek megismerésével. A szakirodalmi háttér feltérképezése alapot nyújtott a vizsgálati módszerek gyakorlatban történő hasznosíthatóságába, így a kutatás folytatásaként a tanulmányban bemutatott módszereket valós körülmények között szükséges tesztelni. Kvalitatív (fókuszcsoportos) majd kérdőíves kutatással feltárhatóvá válik a biometrikus rendszerek felhasználóinak attitüdje, és annak befolyásolására alkalmas eszközei, mellyel célunk a felhasználói elfogadottság széleskörben történő fokozása. 


\section{FELHASZNÁLT IRODALOM}

[1] Tractica (2017) „Biometrics Market Forecasts Executive Summary” Tractica LLC, Boulder, USA

[2] D. Varga és A. Oláh (2004) „Biometrikus azonositó rendszerek, ” Híradástechnika, 7 (14), 40-44

[3] S. Suplicz, B. Főzi és S. Horváth (2006) „Írisz felismerésen alapuló beléptetı rendszer által keltett attitödök és averzív reakciók vizsgálata," in 6. Nemzetközi Mechatronikai és Biztonságtechnikai Szimpózium, Budapest

[4] L. Czúni (2015) Biometria a számitógépes személyazonositásban-vizuális módszerek, Veszprém: Pannon Egyetem

[5] K. Saravanan, C. Saranya és M. Saranya (2012) „A new application of Multimodal Biometrics in home and office security system," in Cornell University, NATIONAL CONFERENCE ON CONTROL, COMMUNICATION AND SYSTEM ENGINEERING, India

[6] T. Hoang és D. Choi (2014), ,Secure and Privacy Enhanced Gait Authentication on Smart Phone," The Scientific World Journal, 2014, 1-8

[7] T. Kovács (2009) Biometrikus azonositás, Budapest: BMF, Főiskolai Digitális Jegyzet

[8] M. T. Jafari, H. Ghamgin és M. S. Akhgar (2013) „Comparison of biometric,” International Research Journal of Applied and Basic Sciences,4(8), 2075-2079

[9] A. Forgács, Z. Kovács, É. Bodnár és J. Sass (2011) Alkalmazott pszichológia az üzleti életben, Budapes: Aula

[10] R. L. Atkinson, R. C. Atkinson, E. E. Smith, D. J. Bem és S. Nolen-Hoeksema (1999) Pszichológia, Budapest: Osiris

[11] R. C. Atkinson és E. Hilgard (2005) Pszichológia, Budapest: Osiris

[12] A. Oláh (2006) Pszichológiai alapismeretek, Budapest: Bölcsész Konzorcium

[13] A. P. Brief és H. M. Weiss (2002) „Organizational Behavior: Affect in the Workplace,” Annual Review of Psychology, 53 pp. 279-307

[14] S. A. Lowery és M. L. DeFleur (1995) Milestones in Mass Communication Research: Media Effects, 3. kiadás, New York: Longman

[15] E. Katz, (1957) „The Two-Step Flow Of Communication: An Up-to-date Report on an Hypothesis," Public Opinion Quarterly, 21, 61-78

[16] E. Katz (1963) „Traditions of Research on the Diffusion of Innovation,” American Sociological Review, pp. 237-253

[17] G. Weimann (1982) „On the Importance of Marginality: One More Step into the Twostep Flow of Communication," American Sociological Review, 47, 764-773

[18] O. Becze és E. Bodor-Eranus (2011), ,Az erösek a gyorsak,” Esély, 5, 30-46

[19] Z. Szántó, „A társadalmi kapcsolatháló-elemzés szociometriai gyökerei,” in A társadalmi kapcsolatháló-elemzés, Budapest, BCE Szociológia és Társadalompolitika Intézet, 2011, pp. 649-662.

[20] F. Mérei (2006) Közösségek rejtett hálózata, Győr: Osiris 
[21] G. Ligeti és G. Héra (2014) Módszertan: A társadalmi jelenségek kutatása, Budapest: Osiris

[22] E. Berghauer-Olasz (2016) „A kinetikus iskolarajz mint közösségek rejtett kapcsolatainak feltáró módszere, Doktori értekezés," PÉCSI TUDOMÁNYEGYETEM BÖLCSÉSZETTUDOMÁNYI KAR Pszichológia Doktori Iskola, Pécs

[23] K. N. Kollár (2004) A társas kapcsolatok, személyközi vonzalom és a csoportfolyamatok, Budapest: Osiris

[24] G. Hoffman (1974), „A társas beilleszkedés problémáinak elemzése több szempontú szociogram alapján," Pedagógiai Szemle, 24 (1), 46-54 